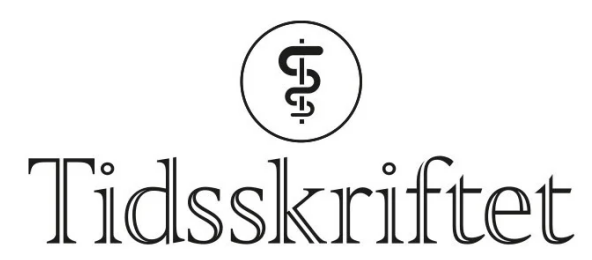

DEN NORSKE LEGEFORENING

\title{
God bok om fortidens pandemier
}

\author{
ANMELDELSER
}

PER HOLCK

Professor emeritus, Institutt for medisinske basalfag Universitetet i Oslo

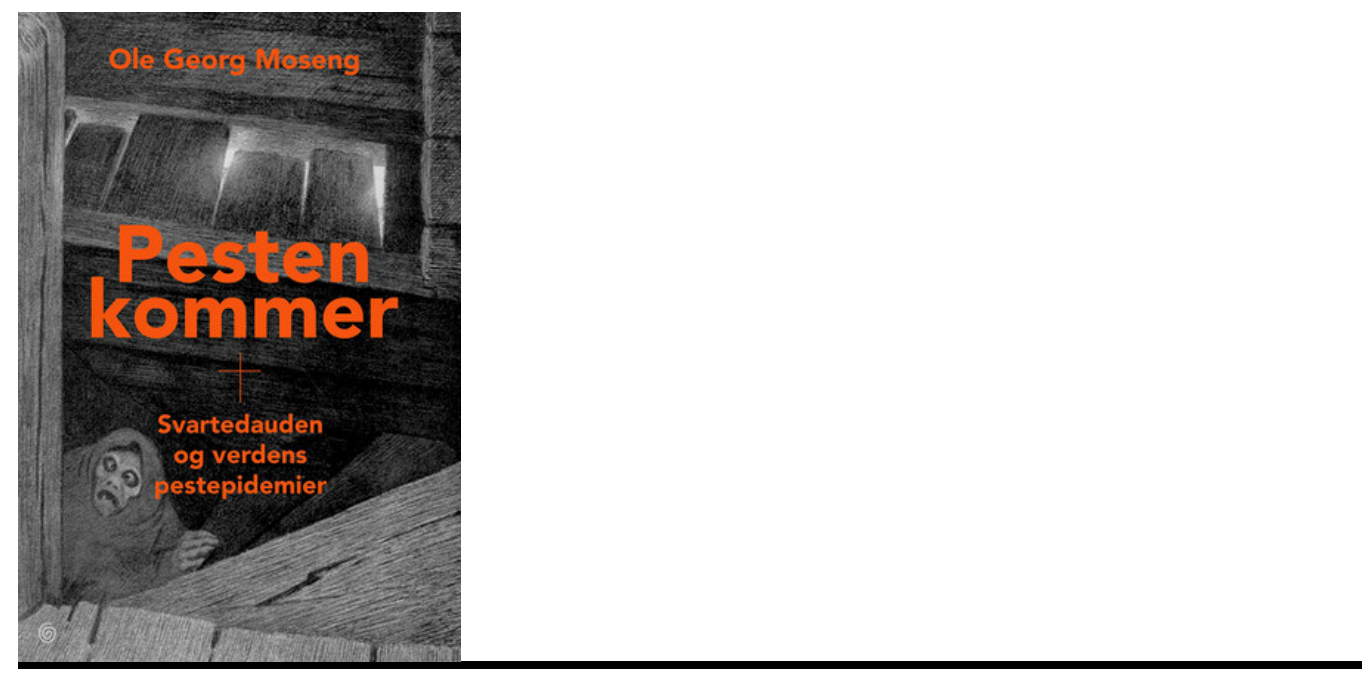

Ole Georg Moseng

Pesten kommer

Svartedauden og verdens pestepidemier. 198 s. Oslo: Kagge Forlag, 2020. Pris NOK 399

ISBN 978-82-489-2626-9

En bok om pestens historie må sies å være aktuell nå i koronatiden. Forfatteren er historiker og har en betydelig produksjon innen temaet fortidens epidemier.

Boken synliggjør et felles mønster i alle epi- og pandemier gjennom tidene. Selv om bakterielle infeksjoner neppe kan likestilles med virusinfeksjoner, forbauses man likevel over hvordan fortidens mennesker tenkte for å stanse smitten. De forsto godt hva smitte var, selv om de ikke kjente årsaken. Forfatteren nevner tiltak fra hundrevis av år tilbake som sannelig kunne måle seg med det vi forsøker å gjennomføre i dag med mer eller mindre hell: isolering, karantene, avsperring og forsø $\mathrm{k}$ på behandling. 
Boken gir en historisk oversikt over pestepidemiene gjennom tidene, fra den justinianske pesten på 5oo-tallet til vår egen tids sporadiske utbrudd, men med fokus på spredningen rundt midten av 13oo-tallet. Utbruddene kom hyppigere enn man skulle tro. Årsakene til den eksplosive spredningen i senmiddelalderen drøftes i lys av hva vi i dag vet om smitte, slik at dette samtidig gir leseren en forståelse av svartedauens epidemiologi.

Noe kritikk bør det likevel være. Forfatteren hevder at lus ikke overfører pest. Det er neppe korrekt, noe som også nylig ble fremhevet i TV-programmet «Pesten i London» på NRK 19.1.2021. Man har derfor tenkt seg at også fugler kan ha fungert som pesttransportører, noe som kanskje kan forklare spredningen over lange distanser på kort tid.

Boken har en rikholdig litteraturliste med hele 136 referanser, men dessverre er det vanskelig å finne den ønskede referansen under lesingen, siden ikke alle angår teksten i boken. Jeg undrer meg også litt over at Ole Jørgen Benedictow ikke er nevnt, til tross for at han kanskje er den historikeren i Norge som har beskjeftiget seg mest med pest.

Også undertittelen - svartedauden - virker for meg litt arkaisk, nesten Ivar Aasensk. Er ikke dauen en brukbar form på bokmål?

Dette er likevel bagateller. Det man heller bør sette fingeren på er bokens layout, som etter min smak er av det kjedelige slaget, med utydelige, svart-hvite illustrasjoner på grovt, gulaktig papir. Kagge forlag burde i stedet benyttet anledningen til å putte inn illustrasjoner fra pestens tid - både miniatyrer og nyere bilder i farger - på godt papir, noe som klart ville økt leserens interesse.

Boken hadde fortjent det. Likevel er den et viktig bidrag til kunnskap om en serie pandemier som i langt større grad har overgått det vi i dag opplever.

Publisert:3. mai 2021. Tidsskr Nor Legeforen. DOI: 10.4045/tidsskr.21.0145

(C) Tidsskrift for Den norske legeforening 2023. Lastet ned fra tidsskriftet.no 26. april 2023. 